\title{
PEMODELAN ISOTERMAL SECARA TIGA DIMENSI (3D) BERDASARKAN MANIFESTASI PERMUKAAN PADA DAERAH SIPOHOLON, KABUPATEN TAPANULI UTARA, PROVINSI SUMATERA UTARA
}

\author{
THREE DIMENSIONAL (3D) ISOTHERMAL MODELING \\ BASED ON SURFACE MANIFESTATION IN SIPOHOLON AREA, \\ NORTH TAPANULI REGENCY, NORTH SUMATERA PROVINCE
}

\author{
Lano Adhitya Permana, Dudi Hermawan, dan Santia Ardi Mustofa \\ Pusat Sumber Daya Mineral, Batubara dan Panas Bumi \\ lano.adhitya@esdm.go.id
}

\begin{abstract}
ABSTRAK
Pemodelan isotermal secara tiga dimensi (3D) pada daerah Sipoholon dilakukan untuk memberikan visualisasi yang lebih baik sehingga mempermudah dalam memahami kondisi temperatur bawah permukaan. Metode yang digunakan pada penelitian ini difokuskan pada pengolahan data geokimia berupa mata air panas yang didukung oleh data geologi dan geofisika, untuk kemudian dilakukan pemodelan 3D isotermal sehingga dapat dilakukan analisis dan interpretasi kondisi temperatur bawah permukaan di daerah penelitian. Hasil pemodelan 3D isotermal menunjukkan bahwa pola isotermal di daerah penelitian dipengaruhi oleh keberadaan sumber panas, struktur geologi dan pola resistivitas. Mengingat keterbatasan data yang dimiliki, hasil pemodelan ini masih merupakan proses awal pemodelan pada sistem panas bumi daerah Sipoholon dan masih memungkinkan untuk dilakukan pembaharuan data dan model lebih lanjut.
\end{abstract}

Kata kunci: Sipoholon, pemodelan, tiga dimensi (3D), isotermal, mata air panas

\section{ABSTRACT}

Three-dimensional (3D) isothermal modeling in the Sipoholon area is carried out to provide better visualization so that it is easier to understand the conditions of subsurface temperatures. The method used in this study is focused on the processing of hot springs geochemical data that are supported by geological and geophysical data, and then 3D isothermal modeling can be carried out so that analysis and interpretation of subsurface temperature conditions can be carried out in the study area. The isothermal 3D modeling results show that the isothermal patterns in the study area are influenced by the presence of heat sources, geological structures, and resistivity patterns. Because of the limited data, the results of this modeling are still an initial process of modeling the geothermal system of the Sipoholon area and it is still possible to do further data and model updates.

Keywords: Sipoholon, modeling, three dimensional (3D), isothermal, hot spring

\section{PENDAHULUAN}

Untuk mengurangi resiko pada tahap awal eksplorasi diperlukan adanya data dan informasi kebumian yang lengkap. Namun demikian, ketersedian data terutama yang terkait dengan data bawah permukaan, seperti distribusi temperatur bawah permukaan masih sangat terbatas keberadaannya.

Isotermal merupakan salah satu data yang biasa digunakan pada tahap awal eksplorasi panas bumi yang berguna untuk memperoleh gambaran temperatur sekaligus kondisi bawah permukaan 
terutama reservoir panas bumi yang menjadi target utama dalam kegiatan eksplorasi panas bumi. Umumnya, penggunaan isotermal pada tahap awal eksplorasi dilakukan dengan penggambaran dua dimensi (2D) melalui peta dan penampang. Namun, informasi tentang kondisi temperatur bawah permukaan yang diperoleh dari visualisasi dua dimensi tersebut ternyata masih terbatas dan kurang lengkap, sehingga mengalami kendala untuk menginterpretasikan kondisi bawah permukaan secara menyeluruh. Model 3D isotermal merupakan salah satu cara untuk memvisualisasikan kondisi temperatur bawah permukaan. Beberapa penelitian tentang pembuatan model isotermal secara tiga dimensi pernah dilakukan oleh Pratama, A.B. dkk (2015) di daerah Gunung Galunggung dan Saputra, M.P. dkk (2016) pada Lapangan Panas Bumi Montelago, Filipina.

Daerah penelitian pada makalah ini dilakukan di daerah Sipoholon yang secara administratif termasuk dalam Kabupaten Tapanuli Utara, Provinsi Sumatera Utara. Lapangan Panas Bumi Sipoholon telah memiliki kelengkapan data berupa data geologi, geokimia dan geofisika.

Anonim (2018) menyebutkan bahwa kontrol struktur geologi, kondisi manifestasi permukaan dan anomali tahanan jenis merupakan faktor-faktor yang dapat digunakan sebagai petunjuk pola isotermal. Keterkaitan antara data geologi, geokimia dan geofisika diduga memberikan pengaruh terhadap pembuatan model 3D isotermal pada sistem panas bumi daerah Sipoholon. Tujuan penulisan makalah ini yaitu melakukan pemodelan isotermal melalui visualisasi secara tiga dimensi (3D), sehingga geometri pola temperatur bawah permukaan pada sistem panas bumi Sipoholon dapat diketahui lebih jelas.

\section{METODOLOGI}

Metode yang digunakan pada penelitian ini difokuskan pada pengolahan data geokimia yang didukung oleh data geologi dan geofisika. Data geokimia yang digunakan berasal dari data manifestasi panas bumi berupa mata air panas. Sedangkan, data geologi yang digunakan meliputi data litologi dan struktur geologi yang diperoleh dari hasil pemetaan geologi. Sementara itu, data geofisika yang digunakan berupa data magnetotelurik yang memuat informasi tentang adanya reservoir panas bumi.

Penentuan kedalaman reservoir merupakan langkah awal dalam pembuatan model 3D isotermal yang diikuti oleh konversi kedalaman reservoir dalam bentuk elevasi, untuk kemudian dihitung nilai sebaran temperatur bawah permukaan.

Selanjutnya, dilakukan pembuatan grid dalam bentuk volume pixel grid (voxel grid) agar dapat dilakukan pemodelan 3D isotermal dengan menggunakan perangkat lunak Encom Discover PA 2013, untuk kemudian dilakukan analisis dan interpretasi kondisi temperatur bawah permukaan berdasarkan pemodelan secara tiga dimensi (Gambar 1).

\section{TINJAUAN GEOSAINS}

Pulau Sumatera merupakan pulau yang terbentuk akibat subduksi Lempeng IndoAustralia yang bergerak dari selatan ke arah utara dan menyusup di bawah Lempeng Eurasia di sepanjang zona subduksi Sumatera (Sieh dan Natawidjaya, 2000). McCaffrey (2009) menjelaskan bahwa subduksi yang terjadi di Pulau Sumatera menghasilkan sesar mendatar. Sedangkan, Muraoka dkk (2010) menyebutkan bahwa selain terbentuknya jalur sesar di bagian barat dari Pulau Sumatera, hasil subduksi Lempeng Indo Australia dan Lempeng Eurasia menghasilkan gugusan gunung api yang berpeluang menghasilkan daerah prospek panas bumi, salah satunya yaitu daerah Sipoholon (Gambar 2).

Litologi yang terdapat di daerah Sipoholon terdiri dari batuan vulkanik, endapan sinter karbonat dan endapan alluvial yang 
berumur Tersier hingga Kuarter (Anonim, 2005). Batuan vulkanik di daerah penelitian diperkirakan berasal dari lima buah pusat erupsi yang berbeda, yaitu Dolok Martimbang, Dolok Palangka Gading, Gunung Api Tua Toba, Dolok Siborboron dan Dolok Jorbing. Secara umum, jenis batuan vulkanik yang terdapat di daerah Sipoholon terdiri dari aliran lava, kubah lava dan jatuhan piroklastik. Aliran lava memiliki komposisi andesitik, bertekstur pofiritik dan di beberapa tempat telah terubah dan mengalami pelapukan. Sedangkan, keberadaan kubah lava dicirikan oleh tekstur afanitik hingga porfiritik, berkomposisi andesitik serta terdapat vesikuler dapat dijumpai pada Gunung Martimbang yang diduga dapat menjadi salah satu sumber panas pada sistem panas bumi daerah Sipoholon. Sementara itu, jatuhan piroklastik mendominasi penyebaran litologi daerah penelitian dengan komponen yang terdiri dari fragmen litik, gelas vulkanik dan batu apung.

Pada daerah penelitian dijumpai adanya sinter karbonat dengan dimensi cukup luas yang merupakan hasil endapan dari fluida panas bumi yang membawa larutan karbonat $\left(\mathrm{CaCO}_{3}\right)$, sedangkan endapan permukaan yang dijumpai di daerah penelitian berupa alluvial yang tersebar di sepanjang Depresi Tarutung. Struktur geologi daerah Sipoholon berupa kelurusan dan sesar - sesar berarah timurlaut-baratdaya, utara-selatan, barattimur dan baratlaut-tenggara. Secara umum, sesar berarah baratlaut-tenggara merupakan sesar yang diduga paling berpengaruh terhadap pembentukan zona Depresi Tarutung (Anonim, 2005).

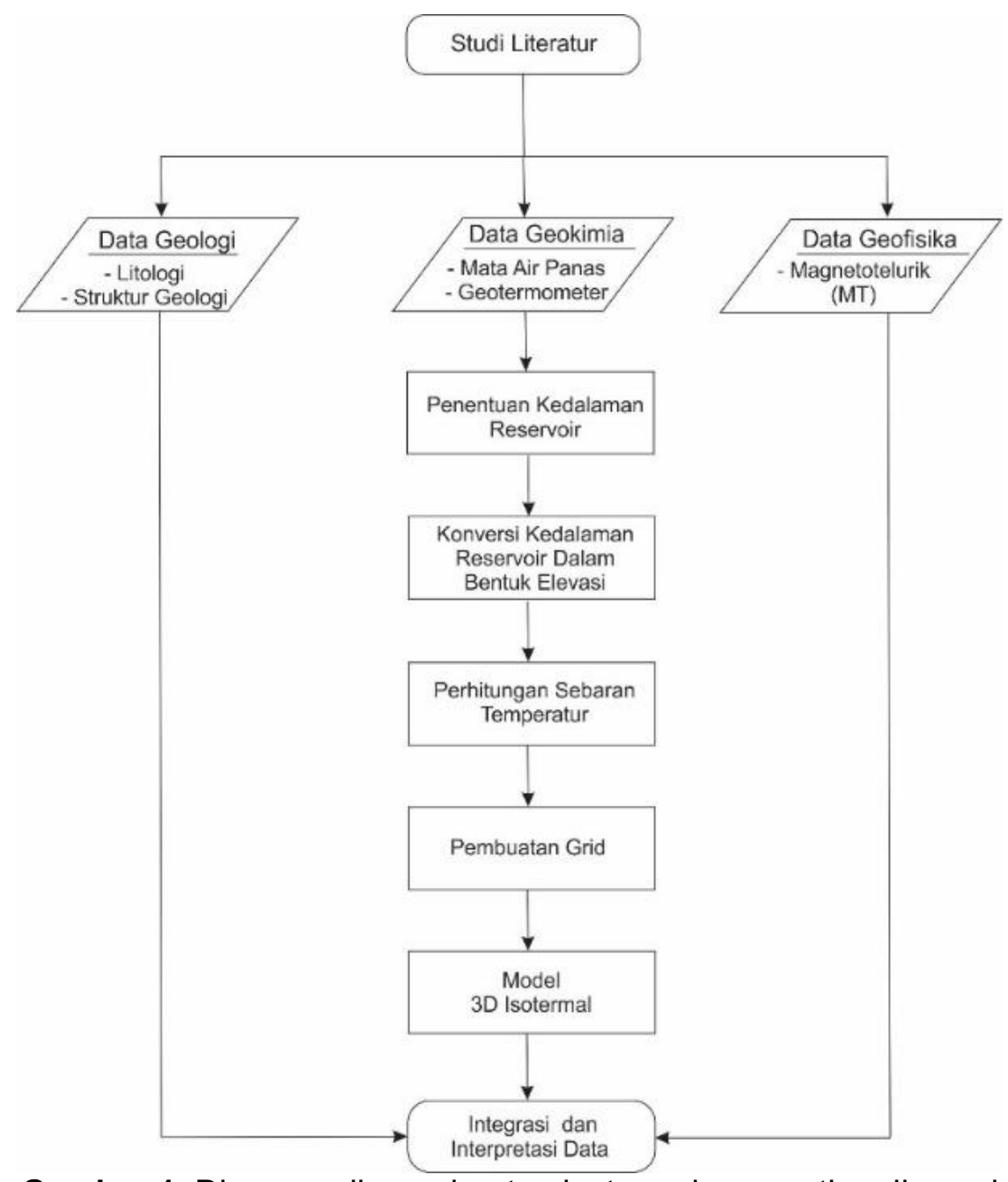

Gambar 1. Diagram alir pembuatan isotermal secara tiga dimensi 


\section{MAKALAH ILMIAH}

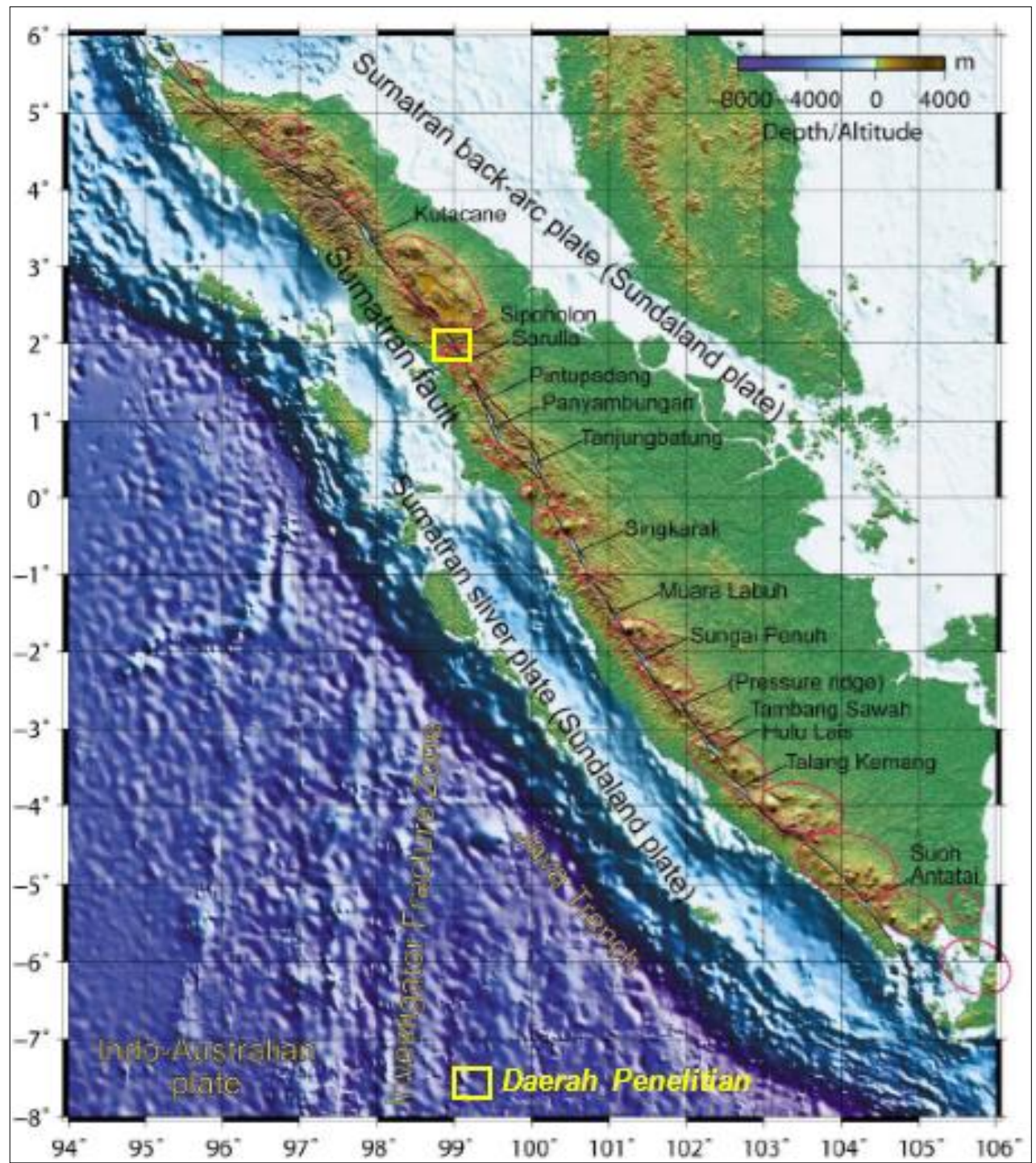

Gambar 2. Peta regional topografi, segmen sesar, pull a part basin

dan gugusan gunung api sepanjang Sesar Sumatera (Modifikasi dari Muraoka dkk., 2010)

Muksin dkk (2013) menyebutkan bahwa keberadaan Depresi Tarutung di daerah penelitian dikontrol oleh sistem Sesar Sumatera dan busur vulkanik muda. Kehadiran struktur geologi di daerah penelitian diduga sebagai pengontrol terbentuknya manifestasi panas bumi. Secara lengkap, penyebaran batuan dan struktur geologi yang terdapat di daerah penelitian dapat dilihat pada Gambar 3.

Anonim (2005) menyebutkan bahwa di daerah panas bumi Sipoholon terdapat manifestasi berupa mata air panas dan batuan ubahan yang sebagian besar muncul di sekitar Depresi Tarutung. Selanjutnya, Anonim (2005) menjelaskan bahwa di daerah penelitian ini terdapat tiga lokasi mata air dingin dan 14 lokasi mata air panas (Anonim, 2005), namun hanya delapan mata air panas yang dianalisis kimia fluida (Tabel 1). Hasil analisis kimia fluida yang direpresentasikan dalam bentuk diagram $\mathrm{Cl}-\mathrm{SO}_{4}-\mathrm{HCO}_{3}$ (Gambar 4), menunjukkan bahwa mata air panas Panabungan dan Hutabarat bertipe air sulfat yang dicirikan oleh kandungan $\mathrm{SO}_{4}$ yang tinggi. Kehadiran ion sulfat yang cukup dominan kemungkinan diakibatkan oleh oksidasi gas $\mathrm{H}_{2} \mathrm{~S}$ di dekat permukaan, sehingga mengindikasikan bahwa jenis fluida tersebut terbentuk di bagian paling dangkal pada sistem panas bumi. 


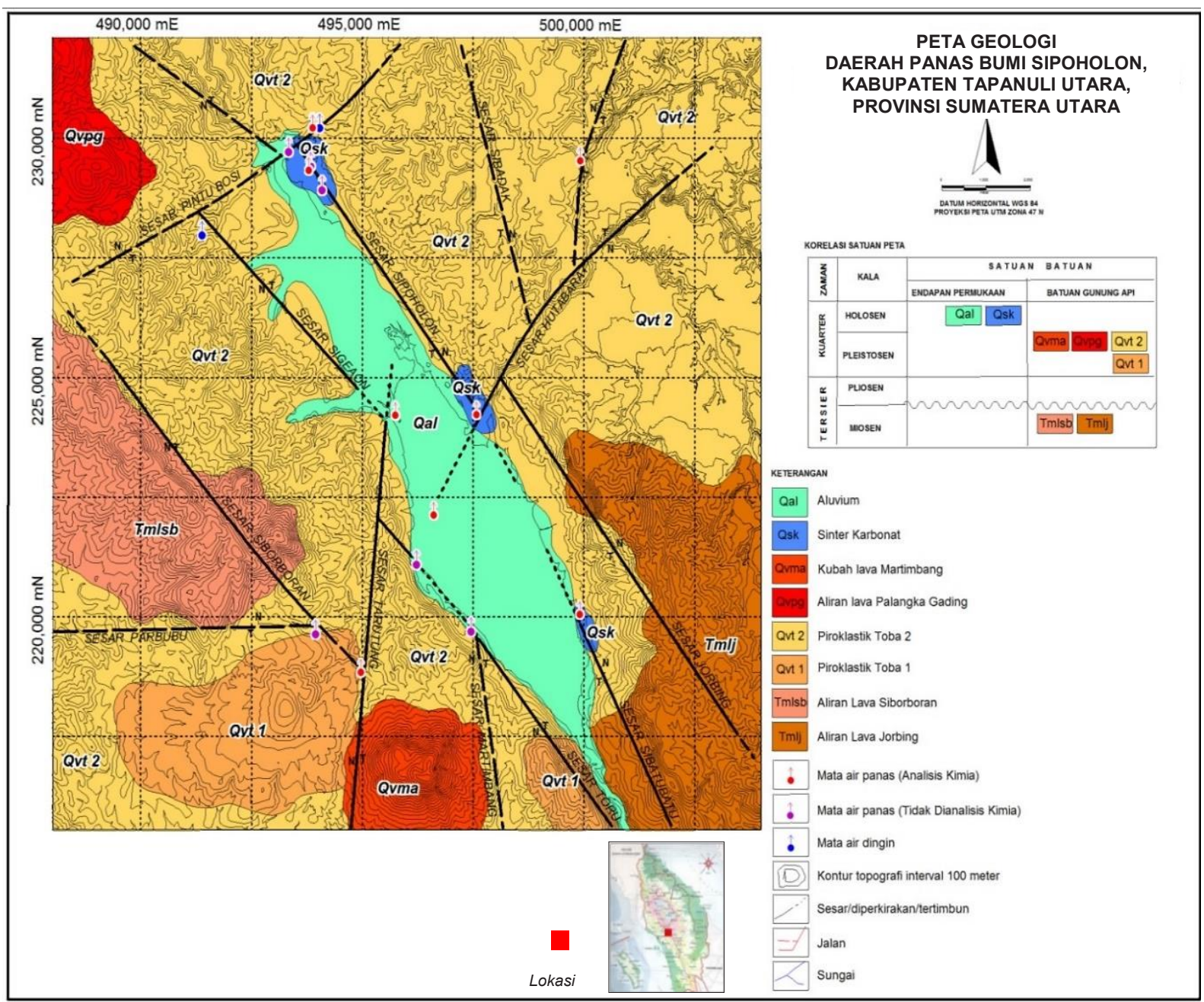

Gambar 3. Peta geologi Daerah Sipoholon (Modifikasi dari Anonim, 2005)

Tabel 1. Karakteristik manifestasi mata air panas dan mata air dingin di Daerah Sipoholon (Modifikasi dari Anonim, 2005 dan Anonim, 2017)

\begin{tabular}{|c|c|c|c|c|c|c|c|c|c|c|c|}
\hline \multirow{2}{*}{ No. } & \multirow{2}{*}{ Manifestasi } & \multirow{2}{*}{ Kode } & \multicolumn{2}{|c|}{ Koordinat (UTM) } & \multirow{2}{*}{$\begin{array}{l}\text { Elevasi } \\
\text { (meter) }\end{array}$} & \multirow{2}{*}{$\begin{array}{c}\text { T. Udara } \\
\left({ }^{\circ} \mathrm{C}\right)\end{array}$} & \multirow{2}{*}{$\begin{array}{l}\text { T.Air } \\
\left({ }^{\circ} \mathrm{C}\right)\end{array}$} & \multirow{2}{*}{$\mathrm{pH}$} & \multirow{2}{*}{$\begin{array}{l}\text { Debit } \\
\text { (L/detik) }\end{array}$} & \multirow{2}{*}{$\begin{array}{l}\text { Daya Hantar Listrik } \\
\qquad(\mu \mathrm{S} / \mathrm{cm})\end{array}$} & \multirow{2}{*}{$\begin{array}{c}\text { T Reservoir } \\
\left({ }^{\circ} \mathrm{C}\right)\end{array}$} \\
\hline & & & $\mathrm{X}$ & $\mathrm{Y}$ & & & & & & & \\
\hline & Bagian Timur Depresi Ta & & & & & & & & & & \\
\hline 1 & Si Ria Ria-1 (Sipoholon) & APSRI-1** & 493804 & 229379 & 990 & 30 & 64.2 & 6.6 & 25 & 1785 & 180 \\
\hline 2 & Si Ria Ria-2 (Sipoholon) & APSRI-2 & 493844 & 229453 & 1011 & 35 & 58.6 & 6.6 & 25 & 1775 & - \\
\hline 3 & Tapian Nauli & APTPN $^{* *}$ & 493893 & 230267 & 988.06 & 27 & 62.5 & 6.4 & 0.5 & $>199.9$ & 180 \\
\hline 4 & Hutabarat & $\mathrm{APHBT}^{* *}$ & 497584 & 224269 & 984 & 28 & 50 & 6.5 & 13.3 & $>199.9$ & 180 \\
\hline 5 & Sait-Nihuta & APSHT ${ }^{\star *}$ & 496628 & 222182 & 949.02 & 27 & 43.2 & 6.3 & 0.05 & 570 & 190 \\
\hline 6 & Sitompul & APSTPL ${ }^{* *}$ & 499916 & 220098 & 967 & 30 & 42 & 6.8 & 0.33 & $>199.9$ & 180 \\
\hline 7 & Panabungan & $\mathrm{APPBN}^{* *}$ & 499928 & 229580 & 1086 & 22 & 48.7 & 6.2 & $>50$ & 1760 & 190 \\
\hline 8 & Sibahu & APSB & 494102 & 228964 & 1010 & 28 & 55.1 & 6.7 & 0.5 & 1897 & - \\
\hline 9 & Lehu & APLH & 493348 & 229757 & 976.05 & 33.2 & 44.7 & 6.5 & 300 & 1325 & - \\
\hline 10 & Sidari (Air Dingin) & APDSDR & 491397 & 228010 & 1044.5 & 27 & 22.4 & 5.3 & 150 & 371 & - \\
\hline 11 & Tapian Nauli (Air Dingin) & APDTPN & 494047 & 230254 & 1002 & 26 & 22.2 & 3.8 & $>50$ & $>199.9$ & - \\
\hline \multirow[t]{2}{*}{12} & Sungai Tapian (Air Dingin) & ADSTPN & 493893 & 230267 & 987 & 27 & 26.3 & 7.7 & $>50$ & 153 & - \\
\hline & Bagian Barat Depresi Tar & & & & & & & & & & \\
\hline 13 & Simamora & $\mathrm{APSM}^{* *}$ & 495752 & 224258 & 942.5 & 28 & 47.4 & 6.7 & 0.08 & 1006 & 190 \\
\hline 14 & Air Soda-Perbubu & APSDPBU & 496229 & 221138 & 950 & 25 & 31.1 & 5.9 & $>50$ & 323 & - \\
\hline 15 & Perbubu Tangga & APPTG & 497470 & 219733 & 975 & 27 & 41.3 & 6.3 & 45 & 556 & - \\
\hline 16 & Ugan & APUGN** & 494975 & 218892 & 1095 & 23 & 39.2 & 7.2 & 1 & 163 & 190 \\
\hline 17 & Aek-Nasia & APANS & 493964 & 219678 & 1094 & 21 & 35.3 & 6.1 & 6 & 635 & - \\
\hline
\end{tabular}

Keterangan :

${ }^{* *}$ : Mata Air Panas Yang Dianalisis Kimia Fluida 


\section{MAKALAH ILMIAH}

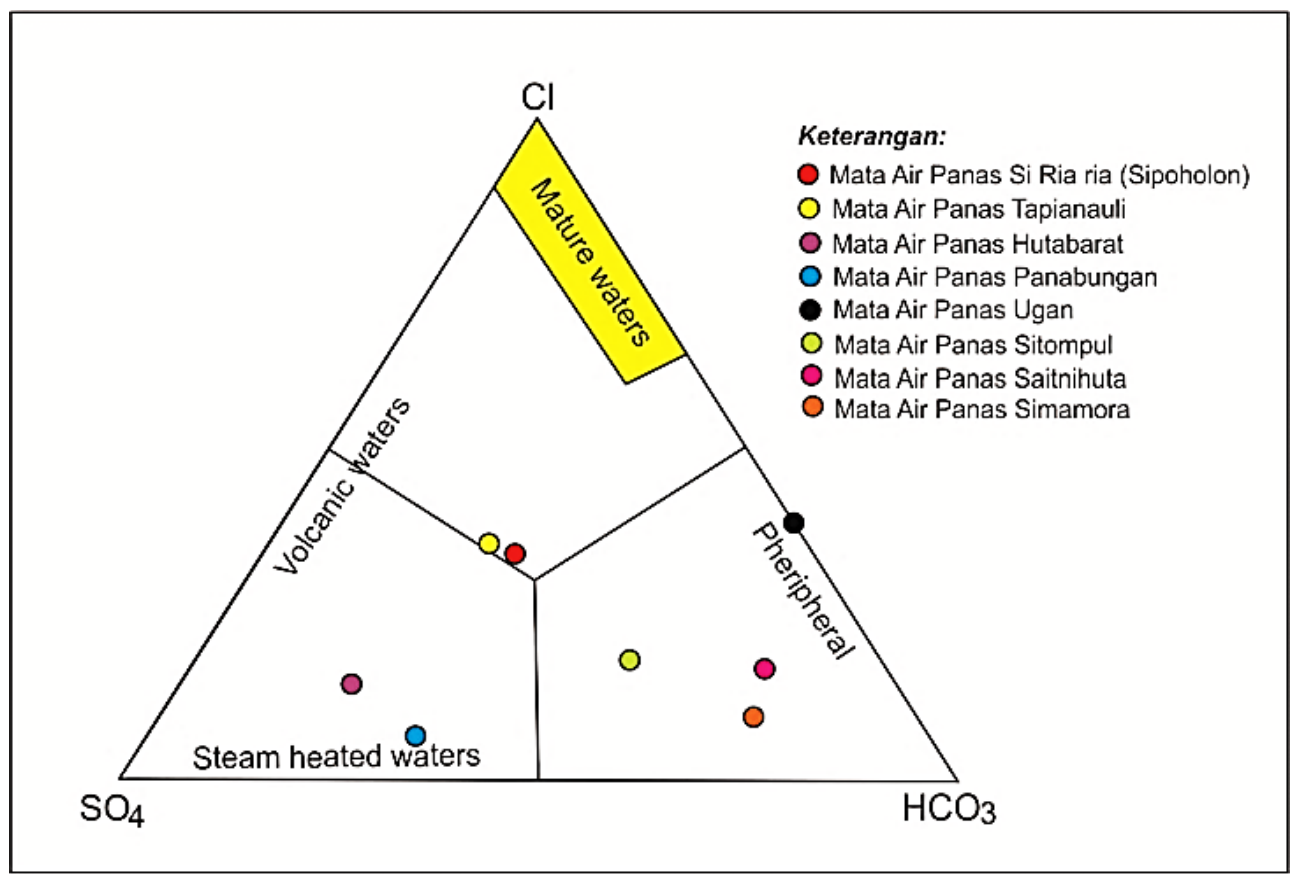

Gambar 4. Diagram segitiga kandungan $\mathrm{Cl}, \mathrm{SO}_{4}$ dan $\mathrm{HCO}_{3}$ (Modifikasi dari Anonim, 2005)

Terdapat dua mata air panas di daerah Sipoholon yang merupakan tipe air klorida namun telah mengalami pencampuran dengan air bikarbonat $\left(\mathrm{HCO}_{3}\right)$ dan air sulfat $\left(\mathrm{SO}_{4}\right)$, yaitu mata air panas Tapian Nauli dan mata air panas Si Ria-Ria atau yang dikenal dengan mata air panas Sipoholon. Sementara itu, mata air panas Sitompul, Saitnihuta, Ugan dan Simamora termasuk dalam tipe air bikarbonat dengan kandungan $\mathrm{HCO}_{3}$ dominan yang diduga terbentuk akibat pengaruh gas $\mathrm{CO}_{2}$ sebagai hasil kondensasi gas atau uap ke dalam air tanah atau air permukaan.

Karakterisik mata air panas Sipoholon dan Panabungan yang memiliki komposisi klorida dan sulfat yang cukup tinggi memungkinkan adanya asosiasi kemunculan bualan-bualan gas yang diperkirakan berasal dari aktivitas magmatik yang terbentuk di kedalaman, sehingga diindikasikan merupakan daerah upflow pada sistem panas bumi daerah Sipoholon. Keberadaan zona upflow di sekitar mata air panas Sipoholon dan Panabungan sekaligus menunjukkan adanya kemungkinan sumber fluida reservoir yang berasal dari kedua mata air panas tersebut.
Kehadiran endapan sinter karbonat dengan dimensi yang luas di bagian timur Depresi Tarutung, diduga berasal dari kandungan Ca yang tinggi sebagai akibat pengaruh dari batuan yang bersifat gampingan di bawah permukaan.

Kandungan $\mathrm{Mg}$ yang relatif lebih tinggi dibandingkan dengan kandungan $\mathrm{K}$ dan $\mathrm{Na}$ mengakibatkan seluruh air panas berada pada zona immature waters (Gambar 5). Hal ini mengindikasikan bahwa mata air panas di daerah penelitian dipengaruhi oleh pencampuran atau kontaminasi dengan air permukaan yang cukup dominan. Pengaruh air permukaan sebenarnya juga terlihat dari tipe air panas di daerah Sipoholon yang didominasi oleh tipe air bikarbonat. Sementara itu, perkiraan temperatur bawah permukaan di daerah Sipoholon dapat dilakukan dengan menggunakan pendekatan mixing model yang menghasilkan kisaran temperatur antara $180^{\circ} \mathrm{C}$ s.d. $190^{\circ} \mathrm{C}$ (Anonim, 2017).

Hasil survei magnetotelurik yang dilakukan oleh Kholid dkk (2010) menyebutkan bahwa terdapat sebaran tahanan jenis rendah di sekitar mata air panas Sipoholon dengan penyebaran ke arah timur (mata air 


\section{MAKALAH ILMIAH}

panas Panabungan), sedangkan Rahadinata (2017) menjelaskan bahwa di daerah Sipoholon, terdapat puncak reservoir dengan kedalaman yang bervariasi dan yang paling dalam muncul pada kedalaman $1.250 \mathrm{~m}$ (Gambar 6).
Hal tersebut menunjukkan bahwa pada bagian timur Depresi Tarutung terdapat anomali tahanan jenis yang mengindikasikan keberadaan batuan penudung dan reservoir sekaligus zona prospek pada sistem panas bumi daerah Sipoholon.

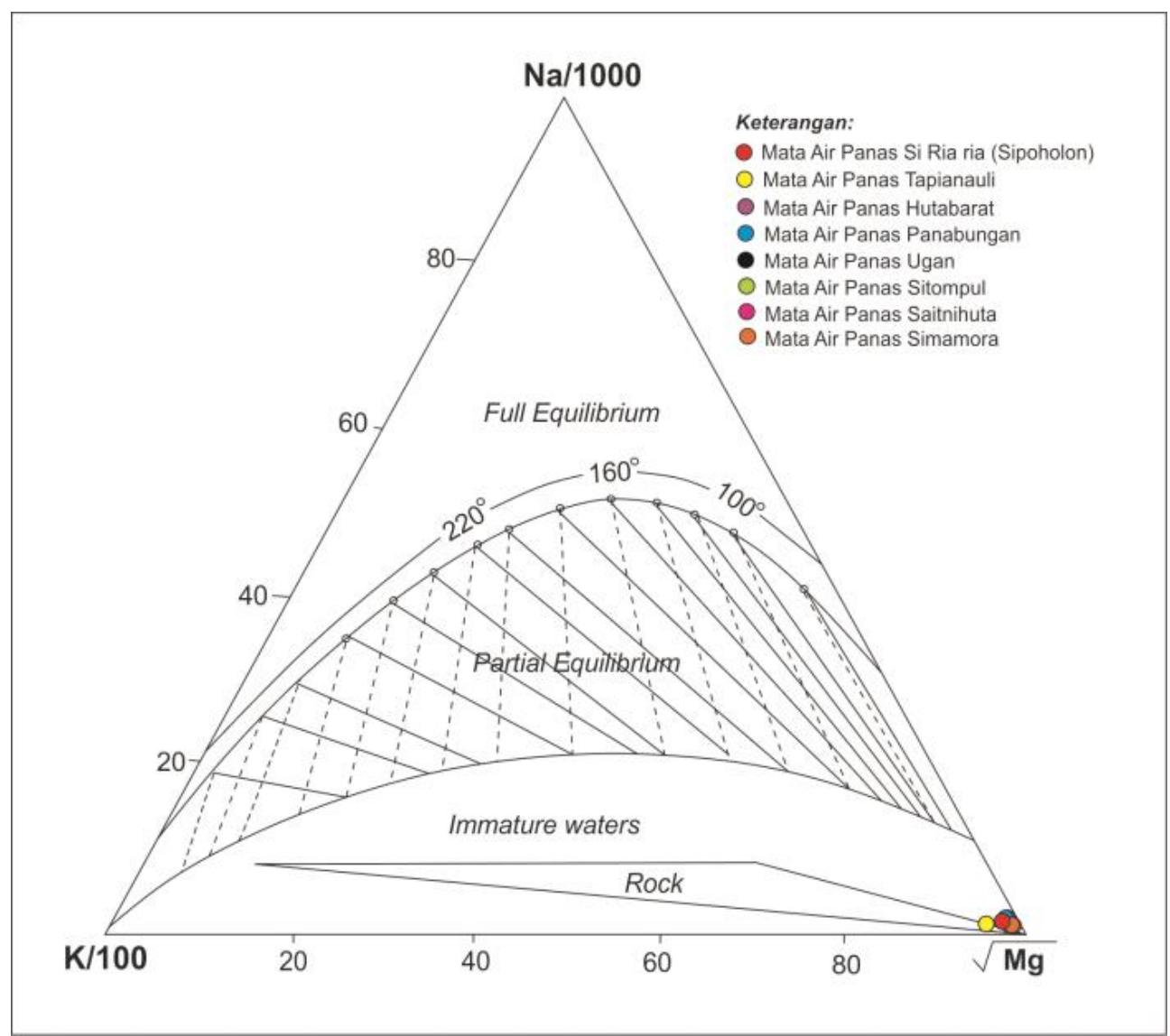

Gambar 5. Diagram segitiga kandungan $\mathrm{K}, \mathrm{Na}$ dan $\mathrm{Mg}$ (Modifikasi dari Anonim, 2005)

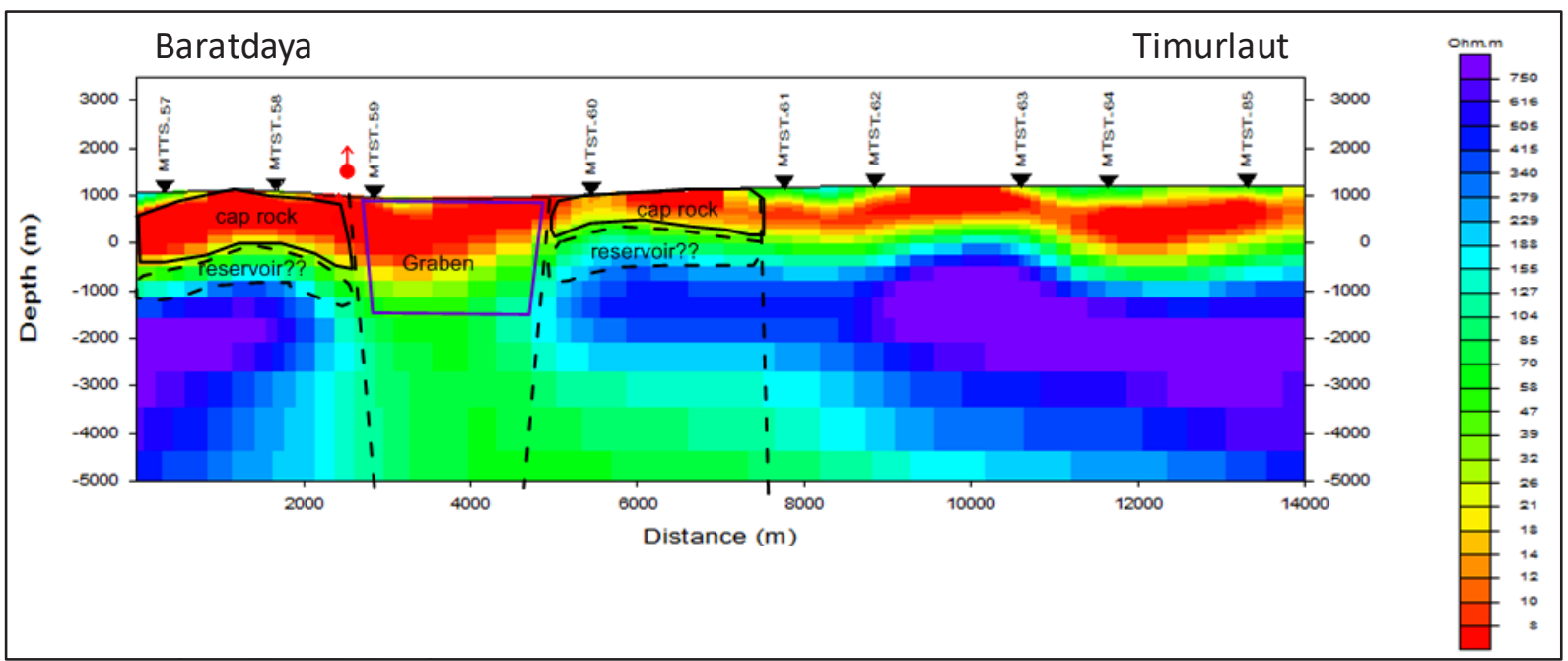

Gambar 6. Model penampang tahanan jenis magnetotelurik (Rahadinata, 2017) 


\section{MAKALAH ILMIAH}

\section{HASIL DAN ANALISIS}

Pembuatan model isotermal pada Lapangan Panas Bumi Sipoholon dilakukan melalui pengolahan data manifestasi panas bumi yang berasal dari delapan mata air panas yang telah dianalisis kimia fluida, yaitu Si Ria-Ria (Sipoholon), Tapian Nauli, Simamora, Hutabarat, Saitnihuta, Sitompul, Ugan dan Panabungan.

Proses pembuatan 3D isotermal diawali dengan penentuan temperatur reservoir berdasarkan data geotermometer yang dilanjutkan dengan penentuan kedalaman reservoir berdasarkan temperatur reservoir dengan menggunakan grafik regresi linear (Gambar 7), seperti yang dikembangkan oleh Hochstein dan Sudarman (2008) (dalam Saputra, M. P. dkk, 2016) melalui formulasi:

$\mathrm{H}_{\mathrm{res}}=8,2 \mathrm{~T}_{\mathrm{res}}-390$

Dimana, $\quad \mathrm{H}_{\text {res }}=$ Kedalaman reservoir $(\mathrm{m})$ $\mathrm{T}_{\text {res }}=$ Temperatur reservoir $\left({ }^{\circ} \mathrm{C}\right)$

Berdasarkan formulasi tersebut, diperoleh kedalaman reservoir di Lapangan Panas Bumi Sipoholon sekitar $1.168 \mathrm{~m}$, sedangkan data magnetotelurik menjelaskan bahwa puncak reservoir diperkirakan berada pada kedalaman sekitar 1.250 meter (Rahadinata, 2017). Dengan demikian, diperkirakan kedalaman zona reservoir di daerah Sipoholon sekitar $1.168 \mathrm{~m}$ s.d. $1.250 \mathrm{~m}$ (Gambar 7). Selanjutnya, kedalaman reservoir tersebut dikonversi dalam bentuk elevasi melalui persamaan berikut ini:
$Z_{\text {res }}=Z_{m}-H_{\text {res }}$

Dimana, $\quad Z_{\text {res }}=$ Elevasi puncak reservoir (m)

$\mathrm{H}_{\text {res }}=$ Kedalaman reservoir $(\mathrm{m})$

$Z_{m}=$ Elevasi manifestasi permukaan $(\mathrm{m})$

Setelah nilai elevasi dari puncak reservoir $\left(Z_{\text {res }}\right)$ diperoleh, maka dilanjutkan dengan perhitungan sebaran temperatur $(T)$ untuk interval kedalaman dari manifestasi permukaan hingga puncak reservoir dengan menggunakan interpolasi linier di bawah ini:

$$
\begin{aligned}
& T=T_{m}+\frac{\left(T_{R e s}-T_{m}\right)}{\left(Z_{R e s}-Z_{m}\right)}\left(Z-Z_{m}\right) \\
& \text { Dimana, } \mathrm{T}=\text { Temperatur }\left({ }^{\circ} \mathrm{C}\right) \\
& \mathrm{T}_{\mathrm{m}}=\text { Temperatur manifestasi } \\
& \text { permukaan }\left({ }^{\circ} \mathrm{C}\right) \\
& \mathrm{T}_{\text {Res }}=\text { Temperatur puncak } \\
& \text { reservoir }\left({ }^{\circ} \mathrm{C}\right) \\
& \mathrm{Z}=\operatorname{Elevasi}(\mathrm{m}) \\
& Z_{m}=\text { Elevasi manifestasi } \\
& \text { permukaan }(\mathrm{m}) \\
& Z_{\text {Res }}=\text { Elevasi puncak reservoir } \\
& \text { (m) }
\end{aligned}
$$

Penerapan formulasi untuk menghitung sebaran temperatur di atas reservoir menggunakan asumsi bahwa interval temperatur bersifat konduktif dan didominasi oleh kehadiran lapisan penudung, sehingga gradiennya dianggap linier (Saputra, M.P. dkk, 2016). Hal tersebut sesuai dengan karakteristik daerah penelitian yang sebagian besar terdapat lapisan penudung. Hasil perhitungan untuk model sebaran temperatur bawah permukaan di daerah penelitian terangkum pada Tabel 2 . 


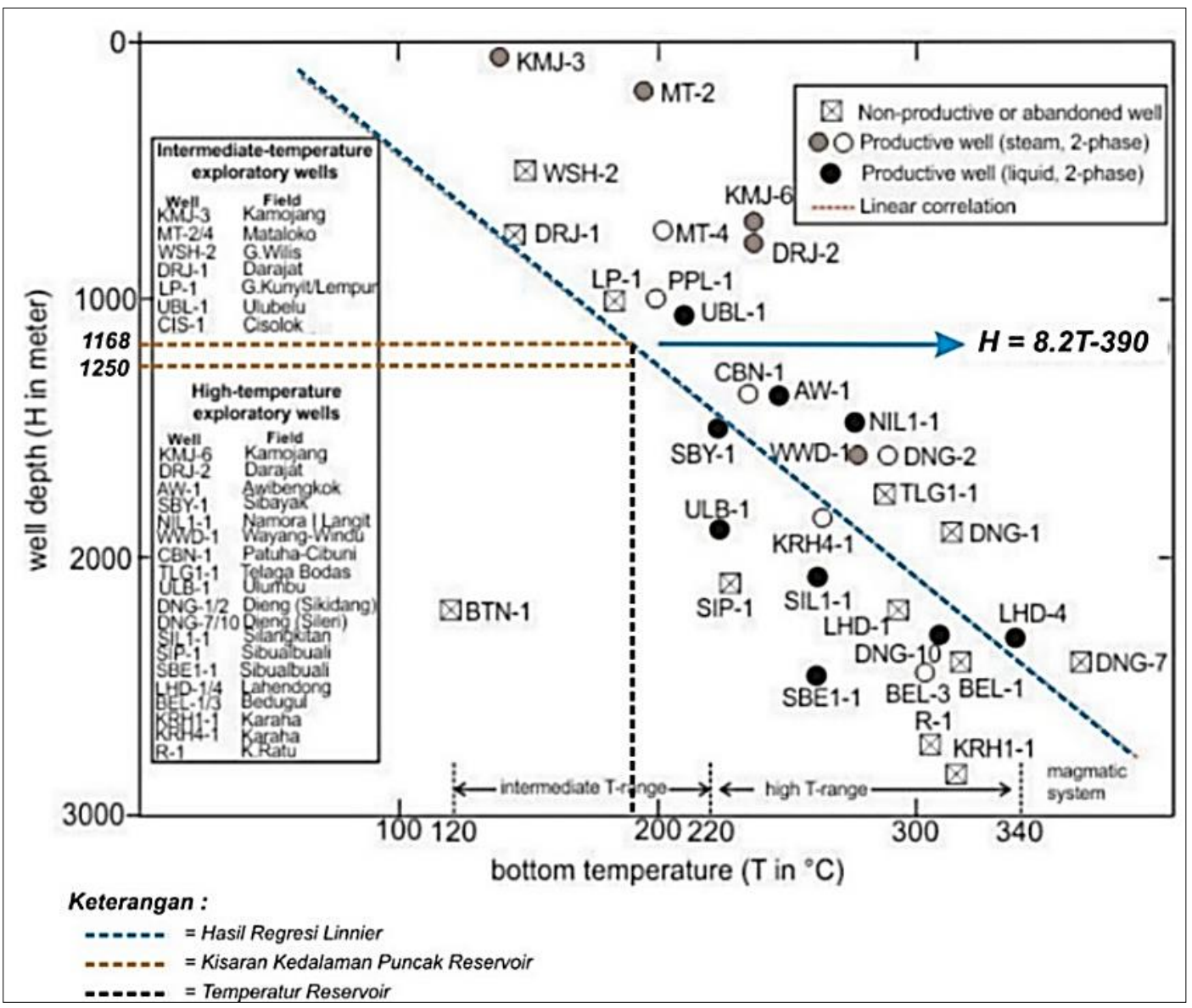

Gambar 7. Korelasi antara temperatur reservoir dengan kedalaman reservoir (Modifikasi dari Hochstein dan Sudarman (2008) dalam Saputra, M. P. dkk, 2016)

Tabel 2. Perhitungan elevasi dari manifestasi permukaan hingga puncak reservoir

\begin{tabular}{|c|c|c|c|c|c|c|c|c|c|}
\hline \multirow{2}{*}{ No. } & \multirow{2}{*}{ Nama/Lokasi } & \multirow{2}{*}{ Kode } & \multicolumn{2}{|c|}{ Koordinat (UTM) } & \multirow{2}{*}{$\begin{array}{l}\mathrm{Tm} \\
\left({ }^{\circ} \mathrm{C}\right)\end{array}$} & \multirow{2}{*}{$\begin{array}{l}\text { Tres } \\
\left({ }^{\circ} \mathrm{C}\right)\end{array}$} & \multirow{2}{*}{$\begin{array}{l}\mathrm{Zm} \\
(\mathrm{m})\end{array}$} & \multirow{2}{*}{$\begin{array}{c}\text { Zres } \\
\text { (m) }\end{array}$} & \multirow{2}{*}{$\begin{array}{c}\text { Hres } \\
(\mathrm{m})\end{array}$} \\
\hline & & & $X(m)$ & $Y(m)$ & & & & & \\
\hline 1 & Air Panas Si Ria Ria -Sipaholon & APSR-1 & 493804 & 229379 & 64,2 & 180 & 990 & -96 & 1086 \\
\hline 2 & Air Panas Tapian Nauli & APTPN & 493893 & 230267 & 62,5 & 180 & 988 & -98 & 1086 \\
\hline 3 & Air Panas Simamora & APDSM & 495752 & 224258 & 47,4 & 190 & 942 & -226 & 1168 \\
\hline 4 & Air Panas Hutabarat & APHBT & 497584 & 224269 & 50 & 180 & 984 & -102 & 1086 \\
\hline 5 & Air Panas Sait Nihuta & APSHT & 496628 & 222182 & 43,2 & 190 & 949 & -219 & 1168 \\
\hline 6 & Air Panas Ugan & APUGN & 494975 & 218892 & 39,2 & 190 & 1095 & -73 & 1168 \\
\hline 7 & Air Panas Sitompul & APSTPL & 499916 & 220098 & 42 & 180 & 967 & -119 & 1086 \\
\hline 8 & Air Panas Panabungan & APPBN & 499928 & 229580 & 48,7 & 190 & 1086 & -82 & 1168 \\
\hline
\end{tabular}

Seluruh hasil perhitungan elevasi dari manifestasi permukaan hingga puncak reservoir dibuat model $3 \mathrm{D}$ isotermal dengan jumlah voxel grid $13 \times 24 \times 4$ dan hanya melibatkan data dari manifestasi permukaan hingga puncak reservoir berdasarkan interpolasi linier.

Hasil pemodelan 3D dari data temperatur bawah permukaan menghasilkan sebaran temperatur pada elevasi tertentu
(Gambar 8), sedangkan keberadaan puncak reservoir yang terdapat di daerah penelitian diperkirakan memiliki pola isotermal seperti yang tampak pada Gambar 9. Anonim (2017) menyebutkan bahwa terdapat sumber panas diantara mata air panas Sipoholon dan Panabungan serta di sekitar mata air panas Ugan yang diduga memberikan pengaruh terhadap geometri pola isotermal di daerah penelitian (Gambar 8). 


\section{MAKALAH ILMIAH}

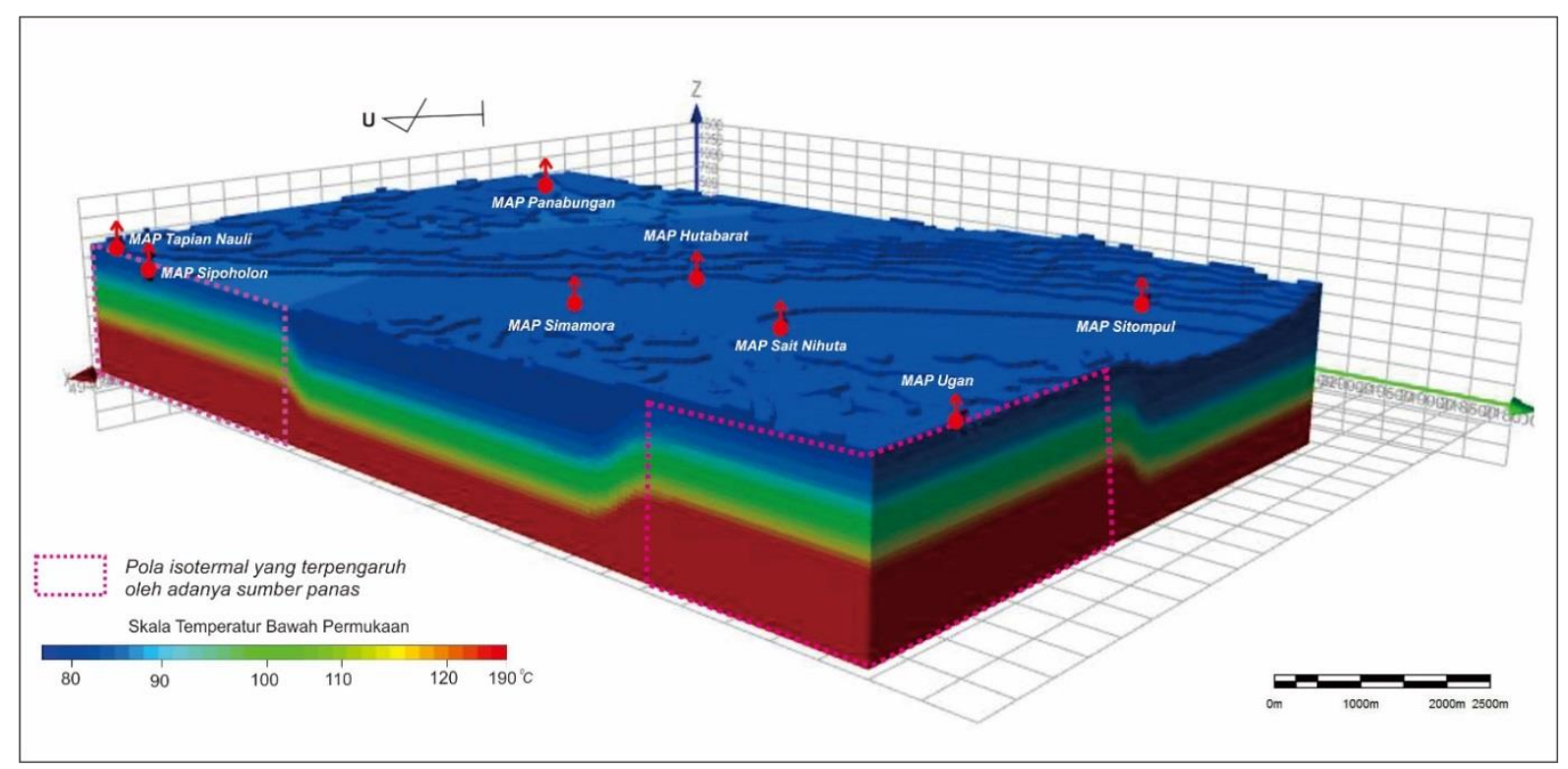

Gambar 8. Model 3D isotermal daerah penelitian

Hasil pemodelan 3D isotermal (Gambar 9), menunjukkan kisaran temperatur $180^{\circ} \mathrm{C}$ s.d. $190^{\circ} \mathrm{C}$ yang merupakan temperatur reservoir, mulai teridentifikasi pada elevasi -73 $\mathrm{m}$ di bagian selatan dari daerah penelitian tepatnya di sekitar mata air panas Ugan, sedangkan pada bagian tengah daerah penelitian temperatur reservoir mulai hadir pada elevasi -102 m.

\section{PEMBAHASAN}

Keberadaan reservoir di daerah Sipoholon didukung oleh hasil pemodelan data magnetotelurik (Gambar 10) yang memperlihatkan adanya zona konduktif (<10 Ohm.m) yang diduga sebagai lapisan penudung (Rahadinata, 2017). Pada daerah penelitian diantara mata air panas Panabungan dan mata air panas Sipoholon terdapat pola lapisan konduktif yang semakin menebal ke arah bagian barat dari daerah penelitian. Pola zona konduktif tersebut diinterpretasikan sebagai adanya struktur graben yang memanjang dengan arah baratlaut-tenggara yang terisi oleh endapan piroklastik Toba yang cukup tebal terutama di sekitar mata air panas Sipoholon dan Tapian Nauli, sehingga diduga keberadaan puncak reservoir yang terletak di bawah endapan piroklastik Toba menjadi lebih dalam. Hal tersebut sesuai dengan hasil pemodelan 3D isotermal yang menunjukkan adanya perubahan pola temperatur dari mata air panas Panabungan menuju mata air panas Sipoholon dan Tapian Nauli yang mengindikasikan adanya keberadaan puncak reservoir yang semakin dalam (Gambar 10).

Meskipun pola lapisan konduktif semakin menebal ke arah mata air panas Sipoholon, namun di sebelah barat mata air panas Sipoholon terdapat penipisan lapisan konduktif dengan disertai adanya bentukan pola menyerupai kubah (doming) yang diduga sebagai reservoir.

Pola kubah ini diperkirakan terbentuk karena adanya transfer panas dari sumber panas yang berinteraksi dengan fluida di kedalaman, sehingga memperkuat dugaan bahwa terdapat zona upflow di sekitar mata air panas Sipoholon. Hal tersebut didukung oleh karakteristik mata air panas Sipoholon yang memiliki komposisi klorida dan sulfat yang cukup tinggi disertai adanya bualanbualan gas yang diperkirakan berasal dari aktivitas magmatik di kedalaman. Keberadaaan pola kubah tidak hanya terdapat di mata air panas Sipoholon, namun dapat dijumpai di sekitar mata air panas Panabungan, seperti yang ditunjukkan oleh data magnetotelurik (Gambar 10). 


\section{MAKALAH ILMIAH}

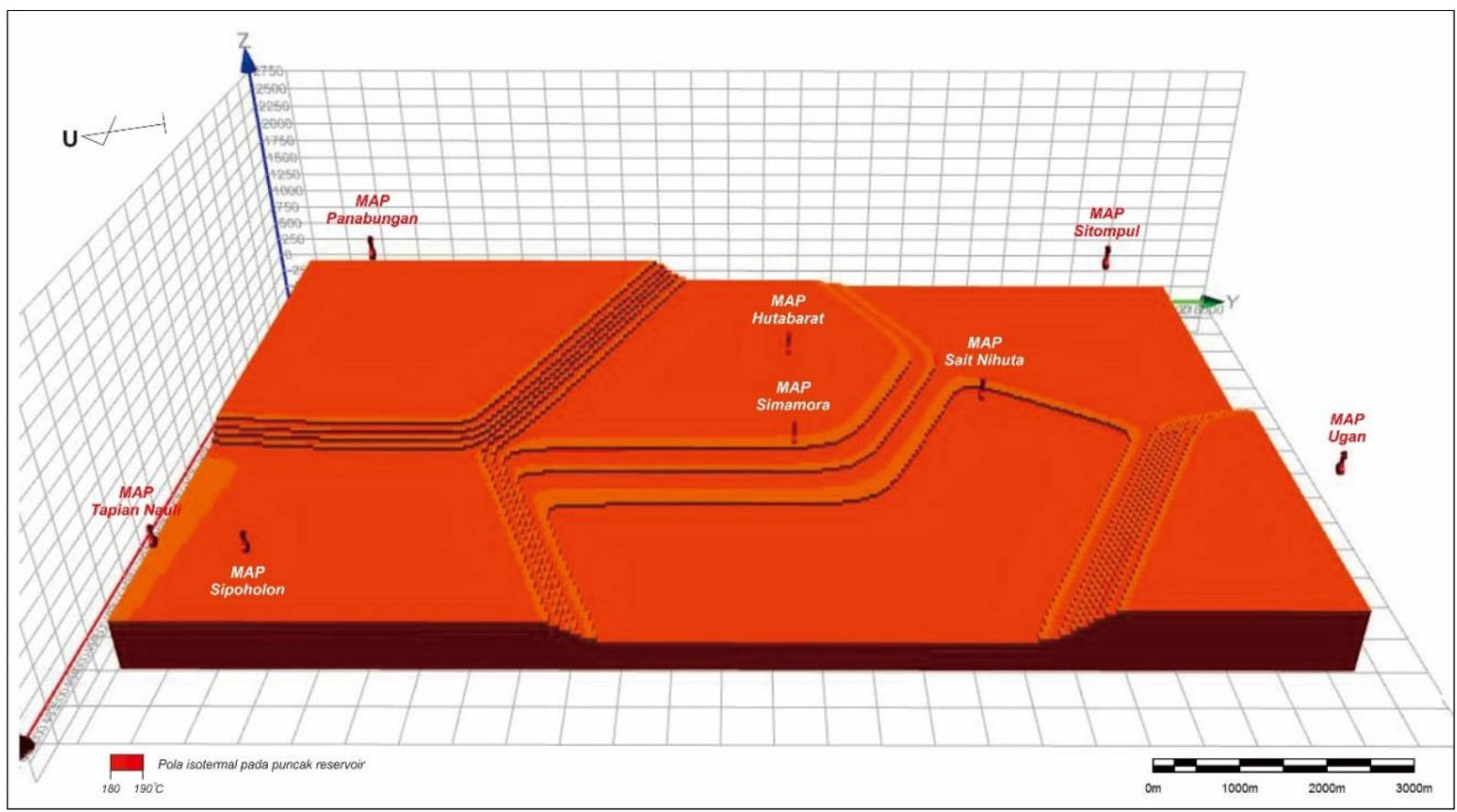

Gambar 9. Model 3D isotermal pada temperatur $180^{\circ} \mathrm{C}$ s.d. $190^{\circ} \mathrm{C}$ di daerah penelitian

Sumber panas di daerah penelitian diduga berasal dari dua wilayah, yaitu pada bagian selatan yang diperlihatkan oleh adanya Kubah Lava Martimbang, sedangkan Anonim (2017) menyebutkan bahwa pada bagian utara daerah Sipoholon tampak adanya pola densitas tinggi diantara kemunculan air panas Sipoholon dan Panabungan di kedalaman, namun tidak muncul di permukaan dikarenakan tertutup oleh endapan piroklastik Toba yang cukup tebal, diinterpretasikan bahwa diantara kemunculan air panas Sipoholon dan Panabungan terdapat magma body yang diduga merupakan salah satu sumber panas pada sistem panas bumi daerah Sipohon. Adanya aktivitas magmatik di wilayah utara dan selatan daerah penelitian, diperkirakan memberikan geometri pola isotermal tersendiri yaitu menyerupai bentuk pola kubah, seperti yang tampak di sekitar mata air panas Ugan (Gambar 9). Keberadaan struktur geologi dapat berperan menjadi media bagi terbentuknya sirkulasi fluida untuk masuk mengisi reservoir panas bumi dan keluar ke permukaan sebagai manifestasi panas bumi berupa mata air panas. Lingkaran merah muda pada Gambar 10 menunjukkan adanya pola perubahan isotermal secara gradasional, diduga dipengaruhi oleh kehadiran struktur geologi yang secara umum memiliki arah baratlauttenggara dan diinterpretasikan merupakan bagian dari Sistem Sesar Sumatera.

Pengaruh aktivitas Sesar Sumatera semakin terlihat jelas pada pemodelan 3D isotermal yang menunjukkan bahwa pada bagian tengah daerah penelitian, puncak reservoir dijumpai pada elevasi yang lebih dalam sebagai akibat terbentuknya Depresi Tarutung. Lebih lanjut, pada Gambar 10 tampak adanya zona-zona konduktif di luar zona reservoir yang mengindikasikan adanya aktivitas hidrotermal. Hal tersebut, ditunjukkan oleh kehadiran batuan ubahan pada daerah penelitian yang berpeluang sebagai batuan penudung pada sistem panas bumi daerah Sipoholon. Namun demikian, mengingat keberadaan manifestasi panas bumi yang digunakan pada pemodelan ini terbatas, maka masih terdapat kemungkinan untuk dilakukan pembaharuan data dan pemodelan lebih lanjut. 


\section{MAKALAH ILMIAH}

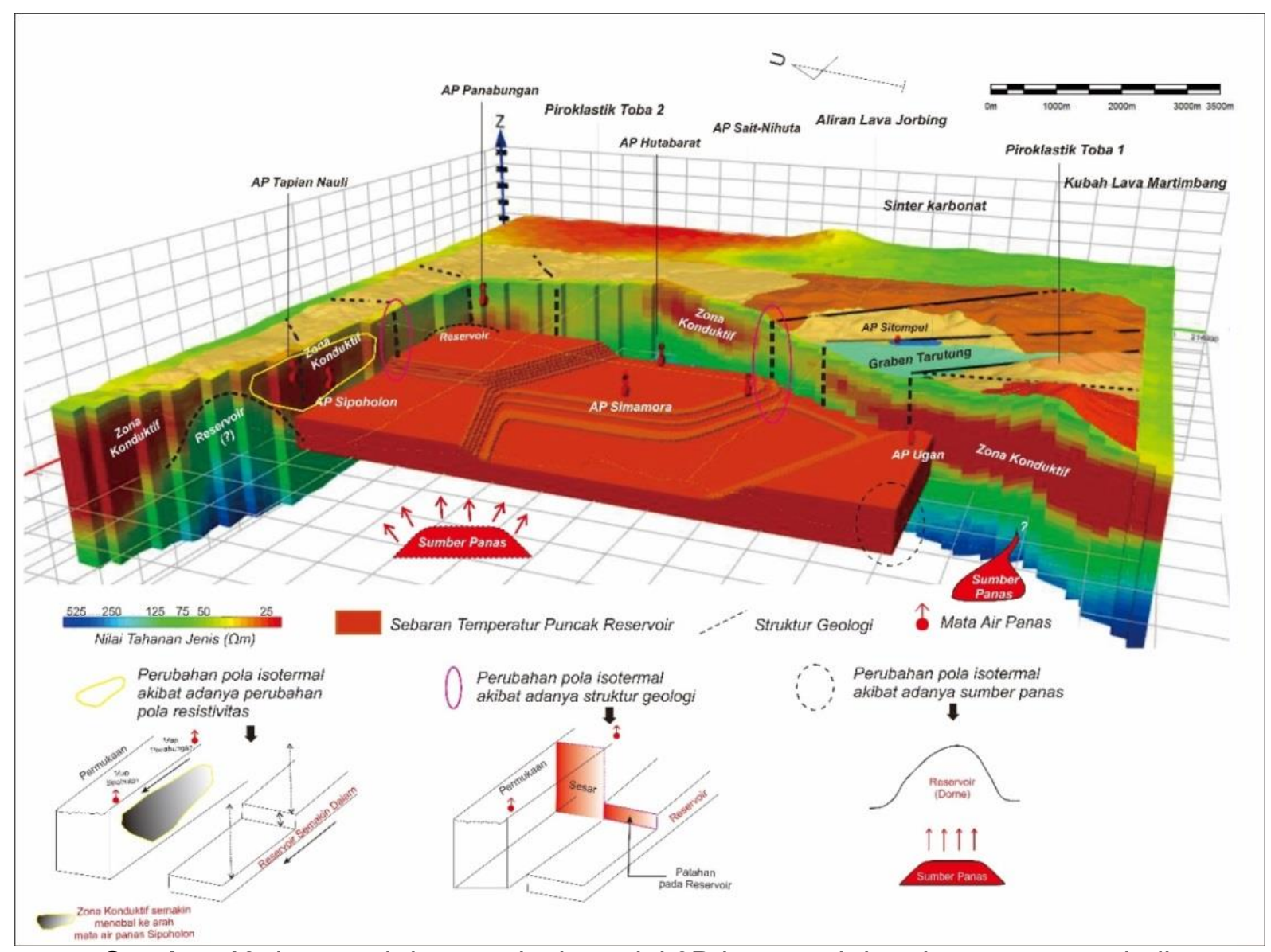

Gambar 10. Integrasi data geologi, model 3D isotermal dan data magnetotelurik

(Modifikasi dari Anonim, 2005 dan Anonim, 2017)

Pembaharuan data dilakukan sebagai bentuk adanya perubahan data terbaru (update data) terkait dengan adanya penambahan data yang digunakan dalam pemodelan 3D isotermal. Dalam hal ini, penambahan data yang diperlukan berupa data manifestasi panas bumi dan data pengeboran. Keberadaan kedua data tersebut sangat penting dan berpengaruh terhadap hasil pemodelan 3D isotermal di daerah penelitian.

Secara umum, hasil pemodelan 3D isotermal menunjukkan bahwa pola isotermal di daerah penelitian dipengaruhi oleh keberadaan sumber panas, struktur geologi, dan pola resistivitas. Model yang dihasilkan diharapkan dapat memberikan visualisasi yang lebih baik sekaligus untuk mempermudah pemahaman tentang kondisi temperatur bawah permukaan di daerah penelitian.

\section{KESIMPULAN}

Hasil pemodelan 3D isotermal pada daerah penelitian dipengaruhi oleh adanya pola resistivitas, kontrol struktur geologi dan aktivitas magmatik. Hal tersebut tampak dari adanya kesesuaian antara hasil pemodelan 3D isotermal dengan pola resistivitas, struktur geologi dan aktivitas magmatik. Keberadaan pola resistivitas dan aktivitas magmatik di daerah penelitian memberikan geometri pola isotermal yang menyerupai bentuk kubah, sedangkan kehadiran struktur geologi berpengaruh terhadap perubahan pola isotermal secara gradasional.

Penggunaan pola isotermal pada daerah penelitian masih belum cukup untuk dapat menentukan daerah yang paling berprospek, sehingga masih perlu didukung oleh data geologi dan geofisika (magnetotelurik). 
Hasil pemodelan 3D isotermal dapat memberikan visualisasi yang lebih baik untuk lebih memahami kondisi temperatur bawah permukaan, sehingga diharapkan dapat dijadikan sebagai bahan pertimbangan untuk memberikan rekomendasi bagi tahapan penyelidikan lebih lanjut, yaitu berupa tahapan pengeboran.

\section{UCAPAN TERIMA KASIH}

Penulis ucapkan terima kasih kepada Kepala Bidang Panas Bumi atas izin penggunaan data untuk penulisan makalah ini. Penulis juga mengucapkan terima kasih kepada rekan-rekan Bidang Panas Bumi yang telah meluangkan waktu untuk berdiskusi, khususnya kepada Bapak Yadi Supriyadi yang telah membantu penyempurnaan gambar dalam makalah ini dan tim editor yang telah memberikan koreksi serta saran dalam perbaikan makalah ini.

\section{DAFTAR PUSTAKA}

Anonim, 2005. Penyelidikan Terpadu Geologi, Geokimia dan Geofisika Daerah Panas Bumi Sipoholon/ Siriaria-Tarutung, Kabupaten Tapanuli Utara, Provinsi Sumatera Utara. Direktorat Inventarisasi Sumber Daya Mineral, Bandung.

Anonim, 2017. Penyiapan Data dan Informasi Sumber Daya Geologi untuk Pengusulan Wilayah Kerja Panas Bumi Tahun 2017. Pusat Sumber Daya Mineral Batubara dan Panas Bumi - Badan Geologi, Bandung.

Anonim, 2018. Modul of Short Term Training Scholarship on Geeothermal Energy Project Management For Middle Level Managers. Foriegn Affairs and Trade Aid Programme, New Zealand.
Kholid, M., Zarkasy, A. dan Widodo, S., 2010. Survei Magnetotelurik Daerah Panas Bumi Sipoholon, Kabupaten Tapanuli Utara, Provinsi Sumatera Utara. Proseding Hasil Kegiatan Lapangan Pusat Sumber Daya Geologi Tahun Anggaran 2010, Buku 1: Bidang Energi. Pusat Sumber Daya Geologi, Bandung.

McCaffrey, R., 2009. The Tectonic Framework of the Sumatran Subduction Zone, Annual Review of Earth and Planetary Science., Vol. 37, h. 345-366.

Muksin, U., Haberland, C., Bauer, K., dan Weber, M., 2013. Three-Dimensional Upper Crustal Structure of the Geothermal System in Tarutung (North Sumatra, Indonesia) Revealed by Seismic Attenuation Tomography. Geophysical Journal International, Vol. 195, h. 2037-2049. DOI: 10.1093/gji/ggt383

Muraoka, H., Takahashi, M., Sundhoro, H., Dwipa, S., Soeda, Y., Momita, M., dan Shimada, K. 2010. Geothermal System Constrained by the Sumatran Fault and Its Pull-Apart Basin in Sumatera, Western Indonesia. Proceedings World Geothermal Congress 2010, h. 1-9. Bali, Indonesia, 25 - 29 April 2010.

Pratama, A.B., Srigutomo, W., dan Suryantini, 2015. 3D Conceptual Modeling Based on Geological Information for Targeting Geothermal Prospect Area in Hidden Geothermal System. Proceedings Fortieth Woekshop on Geothermal reservoir Engineering, h.1-12, Standford, California , 26 - 28 Januari 2015.

Rahadinata, T., $2017 . \quad$ Survei Magnetotelurik (MT) dan Time Domain Electromagnetic (TDEM) Daerah Panas Bumi Sipoholon, Kabupaten Tapanuli Utara, Provinsi Sumatera Utara. Pusat Sumber Daya Mineral Batubara dan Panas Bumi Badan Geologi, Bandung. 


\section{MAKALAH ILMIAH}

Saputra, M.P., Suryantini, Catigtig, D., Regandara, R., Asnin, S.N., dan Pratama, A.B., 2016. Geological, Isothermal and Isobaric 3-D Model Construction in Early Stage of Geothermal Exploration. IOP Conference Series and Environmental Science 42012009. DOI : 10.1088/1755-1315/42/1/ 012009.
Sieh, K., dan Natawidjaya, D.H., 2000, Neotectonics of the Sumatran Fault, Indonesia. Journal of Geophysical Research, Vol.105, No. B12, h. 28,295-28,326, December 10, 2000.

$\begin{array}{ll}\text { Diterima } & : 27 \text { Februari } 2019 \\ \text { Direvisi } & : 8 \text { Maret } 2019 \\ \text { Disetujui } & : 24 \text { Mei } 2019\end{array}$

